\title{
The Model of Teaching Listening Skills to Postgraduates with Disabilities and Special Needs in the Educational Podosphere
}

\author{
Elena Malushko \\ Volgograd State University, \\ Foreign Language Communication \\ Department, \\ Volgograd, Russia \\ e.malushko@volsu.ru
}

\author{
Oxana Maletina \\ Volgograd State University, \\ Foreign Language Communication \\ Department, \\ Volgograd, Russia \\ o.maletina@volsu.ru
}

\author{
Valentina Tsybaneva \\ Volgograd State Academy of Postgraduate \\ Study, \\ Foreign Language Chair, \\ Volgograd, Russia \\ valentinatsybaneva@yandex.ru
}

\begin{abstract}
Nowadays teaching in the podosphere is becoming even more popular because it attracts the maximum number of students regardless of age, sex, education, abilities; provides access to the educational and methodical materials; supports interaction between teaching staff and students. The podosphere is a more interactive teaching tool than listening to a CD or MP3player: podcasts are used to develop first listening skills and then communicative skills of postgraduates through discussion of audio and video fragments, creation of individual podcasts through Talk, Audacity, Movavi or iSpring, which improves the quality of education. This paper is aimed at considering some peculiarities of forming listening skills and the advantages of using educational podosphere as an interactive model of forming listening skills among postgraduates, especially among those having specific medical conditions; explaining why it's necessary to form and develop listening skills of postgraduates according to some aspects of federal state standard of training masters. Two last paragraphs contain instructions how to create and use podcasts to teach listening to different kinds of students. In conclusion, authenticity, interaction and profile orientation of this technology increases the effectiveness of forming foreign profile listening competence of postgraduates due to their availability and adaptive options.
\end{abstract}

Keywords - podcast, podosphere, podocommunication, special needs, disability, recipient

\section{INTRODUCTION}

Under changing world political and economic conditions, the search of optimal means of teaching foreign languages and cultures led educational experts to traditional paradigm shift and opened way to various pedagogical methods such as interdisciplinary projects, role plays, case studies and infocommunication technologies. Each technology has a profound potential which contributes to forming professional competence at a good level. It is obvious that modern education standards and educators themselves have been paying greater attention to innovations, technologies and virtuality recently.

Infocommunication technologies are the combination of digital technologies: methods, industrial processes, programmes and technical means which are aimed at creating, collecting, processing, saving and transmitting, using information due to teaching tasks [1, p. 1155-1160]. Thus, these technologies include computer equipment; cellular, satellite and multimedia means; software; wireless and cable networks; Internet.

Nowadays we turn to Internet technologies and remote support because they allow attracting students from everywhere, providing greater access to the methodical materials and discontinuous connecting between professors and students. Teaching in the podosphere (from English 'iPod' and 'sphere') is one of such technologies and includes podcast terminals and services [2, p. 23].

Podcasts correspond to listening competence because they have sound and video tracks, are mostly free to share and easy to be downloaded or simply played online [3]. Accordingly, teaching in the podosphere has the following advantages: 1) students can get actual authentic information which enriches their speech patterns, broadens their listening and cognitive horizons, motivates them to study foreign languages by forming positive cognitive interest in other cultures; 2) listening and creating podcasts help to form and develop profile competence because students need to research a lot of podcast resources before they manage to find the suitable one. A deep studying can make us more and more interested in the research subject, and the same mechanism appears when studying podcasts which gives students a deep sense of involvement into the process of learning. But podcasts are asynchronous and represent one-sided communicative process, in other words, perception of relevant information with a possible delayed feedback or discussion (student=recipient). In the process of creating podcasts students change their role and become authors. Asynchronism of podocommunication allows all the participants to take part in the foreign language communication at any time and from any place when they are at the university or at home. Thus, professors can also leave assignments in the Internet and then check them at any time.

The same concerns the situation when we adapt our educational environment to students with special medical conditions. They need to have access to materials, teachers and support, and the level of inclusion depends on the level and nature of their disorders. Let us take students with physical disorders just preventing them from frequent leaving the place. If they have no other concomitant disfunctions or disorders, 
their environment does not need to have additional features like sizable text, text-to-speech and speech-to-text reporting and others.

The paper contains the following sections: the first section describes why it is becoming popular to use podcasts to form listening skills; the second section considers strategic educational aims of the Russian education in the 21 st century and the peculiarities of forming listening skills; the third section analyses podocommunication in forming listening skills among postgraduates with and without disorders, creating podcasts and instructions how to teach using this technology. The conclusion summarizes the results of the study which show the effectiveness of using podcasts to develop listening skills among the aiming group of students.

\section{STRATEGIC EDUCATIONAL AIMS AND PECULIAR FEATURES OF TEACHING LISTENING}

\section{A. Educational aims and the federal state educational standards}

Under the Russian integration process into the European and world space employers place new tough requirements when they hire their employees because they need specialists with high qualification, that's why the content of study in institutions of higher education is oriented to developing cognitive and creative skills [4, p. 615].

The strategic aim of the education in the 21 st century is to provide continuous education, so that every person should have the opportunity and necessary conditions to study during all life. In the system of general education there is a non-linear shift to the federal state education standard of the general education. We should note that at present students are taught in accordance with the state educational standard approved in 2004, and their level of competence is checked by the Russian National Exam (RNE). As we have mentioned before, there are some processes connected with the Russian integration into the European educational space, that's why there are some tough requirements to training bachelors and masters at universities because the main aim is to develop skills of international communication applied to their professional activity.

In order to achieve the above-mentioned aim, it's necessary to form a foreign language listening competence. Consequently, it's important to guarantee students the conditions which will lead to gaining profound knowledge and improving their competences, so that they will have a transition period between a school and a university.

Thus, bachelor-students when they continue to study foreign languages at institutes have several difficulties: increase of independent work, change of the control system, complicated material, and professional specialization. Therefore, school graduates should be adapted to the educational process of studying at institutes, because the pedagogical basis of such system is the development of the study content.

The study content includes exercises of different types aimed at developing skills of reading professional scientific literature, of communication, and of listening.
Hence the functional realization of the educational system is connected with the following difficulties: small quantity of classes (144 hours), low motivation, and low level of knowledge. Thus, professors fail to teach students to read in the original: special professional literature, newspapers, journals, materials from on-line resources. Consequently, this failure means that there is no successful realization of the practical aims of the programme.

If we compare the quantity of classes in bachelor's and master's training, we will see the following: bachelors study foreign languages for 144 hours, and masters have only 108 hours to gain their professional foreign competence [5, p. 399].

According to the federal state standard of higher professional education foreign language is a compulsory discipline for postgraduates who choose speciality 'Sociology' as their master's degree. The aim of their study is to train specialists with the following competences: linguistic (including skills of reading, listening, speaking, writing and translating), sociocultural and interactive. The main task is to form a translation competence that is they should understand information in professional foreign texts and translate it into their own language. Postgraduates should be ready to analyse professional information in foreign texts using their linguistic, sociocultural and interactive competences. As a result, students can use Russian and foreign languages as a means of business communication [6, p. 175].

Thus, the federal state standard of higher professional education requires students to understand dialogues and monologues of everyday life and professional communication, that's why forming and developing listening skills include foreign communicative competences such as linguistic, sociocultural and interactive.

\section{B. Peculiarities of forming listening skills}

Foreign language is a compulsory discipline for postgraduates studying different courses, that is why the main aim of a professor is to prepare students to communicate in various professional situations [5, p. 399-405]. The following forms of developing and improving professional communication skills are used: development of business contacts; presentation of research projects; translation, annotation and rendering; writing a resume. Students should understand professional speech, that's why the task of teaching listening is to form the following aspects of professional communication competence: linguistic (listening, reading, speaking and translating skills), sociocultural and interaction.

Before we start analysing the peculiarities of forming listening skills, we should consider the main aim of listening in the professional foreign communication. Listening is a perception activity which includes different logic operations connected with analysis, synthesis, deduction, induction, comparison and etc. The aim of listening is to get new information from the recorded text despite difficulties which include new unknown words, grammar constructions, rhythm of speech, peculiar pronunciation. But the process of teaching listening involves forming listening skills which lead to the perception of form and content of utterances. Of course, if we talk about students with specific health needs, like listening 
difficulties or deafness, teaching listening starts to attract some compensation techniques, including perception of gestures, body movements, vibrations of air and speechreading. This happens because the students tending to listen have hearing problems. Other health disorders do not usually interfere with the listening process [1].

There are the following mechanisms of speech perception: speech hearing, memory, concentration, anticipation and understanding [7], that is why listening is the most complicated process of understanding recorded speech which includes perceptive and thinking activities. In order to realise educational aims it is necessary to teach students to switch their attention from general understanding to detailed understanding of information, and to form prediction skills [8].

If we consider the levels of listening, we can distinguish the following: elementary (forming perception base), intermediate (developing listening skills), advanced (improving speech activity when students are listeners or recipients). These levels are interconnected because perception is the base for forming listening skills which contribute to the improvement of professional foreign communication. Thus, elementary level is supposed to form mechanisms of perceiving the recorded speech, intermediate level is to form understanding skills, advanced level is to develop skills of foreign communication.

We think that it's expedient to divide the lesson into three stages:

1) preparatory tasks which are done before listening to the recorded text (practicing the pronunciation of the following words taken from the text which students are going to listen to; giving Russian equivalents to the following English words and word combinations);

2) tasks which are done while listening (listening to the text and making notes for the first time about the numbers, geographical, proper or personal names which might be heard; when students are listening to the text for the second time, they try to catch the events and their order; agreeing or disagreeing to the following statements; filling in the gaps using the following words);

3) tasks which are done after listening (answering the following questions; matching the following synonyms/phrases from the text (sometimes more than one combination is possible); doing creative tasks: roleplay the dialogue using information from the recorded text, prepare a project with presentations, write a magazine article, write a letter).

This division is evident, because there is a gap in bachelors' and masters' study: bachelors at any speciality usually study foreign languages in their first year, and masters have to study foreign languages three years later after they finish their bachelors' studies.

As students do not have opportunities to study foreign languages at least for 3 years, they have certain difficulties when they have to listen to the recorded texts and to perceive the sense, and then they need to express their opinion. All texts should be connected with the material which is studied during reading lessons, and the preparatory tasks before listening play the prominent role because they help to anticipate and introduce new lexical material.

Thus, teachers when they form listening skills among postgraduates should teach students to switch from general content to detailed information of the recorded text and anticipate [9, p. 39-52].

\section{PODOCOMMUNICATION IN FORMING LISTENING SKILLS AMONG POSTGRADUATES}

\section{A. Creating podcasts to teach listening}

The podosphere is a more interactive teaching sphere than listening with the help of CD or MP3, because it develops critical thinking and improves flexibility in teaching languages. These advantages are connected with the following: podcasts are used not only to develop listening skills but they also allow to improve communicative skills when students participate in discussions of the obtained audio and visual information and when they create their own podcasts using program means like Talk and Audacity.

As we remember, there are two types of podcasts according to the content type they provide: audio and video. Audio podcasts are mostly created in the MP3 format to be compatible with all computers and portable multimedia. They have small size (at about $10 \mathrm{MB}$ ) and are easily created. The creation of video podcasts requires much time and good planning, and their size is more than $100 \mathrm{MB}$. The suitable and preferable format of video podcasts is .mov or .mp4, and recipients can listen and watch such podcasts using different types of computers: Mac, Windows, Android.

But there is one more type of podcasts which combines audio and slide show and include several pictures with URL references. Apple, Sony, Mac, Windows with Itunes can be used to watch and to listen to such podcasts. The great advantages of this podcast type are their small size and their audio and video content [3].

Let's look at the typical stages of creating podcasts:

1) definition of a topic and search for an idea of the podcast;

2) preparation of the equipment (microphone, different filters, camera, recorder);

3) record of a podcast (different programmes and audio editors);

4) edition (sequence synchronization, music addition);

5) publication (any podcast can be published on a website and podcast terminal) [3].

When students create a podcast, they have to find a topic connected with their educational aim, so they need a teacher's or tutor's help to do this task. Then there occurs a discussion of the podcast's content. So, the teacher should consult students where to find relevant educational information. After the discussion there comes another stage of writing a script which is checked by the teaching staff or the tutor obtained a qualification in the IT sphere. Before students are ready to 
record their texts, they need to practice their reading of a podcast's script. Here again, we find some peculiarities. If our students have communication difficulties concerning hearing or speaking, so we have to divide them in some groups and spread the specific tasks to make them involved. This is super important as our task is not just to teach communicative skills but also to let students communicate in any case and by any means. This is the vital prerequisite of socialization of different group of students within the educational and future professional environment.

Thus, students need to have some equipment and microphone to record their podcasts in MP3: they can use their own computer with microphone, mobile, camera, headphones and speakers. If teachers decide to record their students in a classroom, they need to use any MP3 player with record function and it should be portable. The language lab is also appropriate.

When the recorded material is ready, students have another stage of processing it with the help of Audacity or a program alike. Audacity is a free resource widely used by podcasters because this program allows adding music and sound effects besides editing. The whole process can be presented as following:

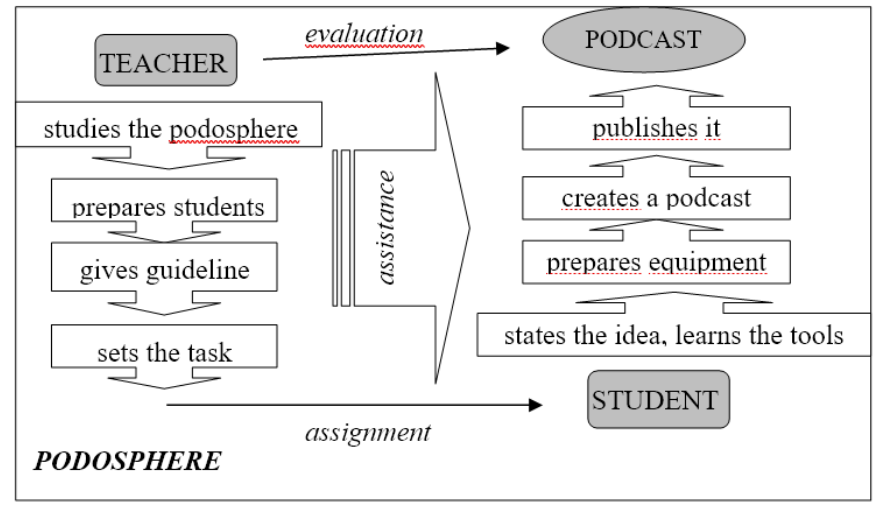

Fig. 1. The procedure of creating a podcast in educational framework

The teaching staff and students who create their own podcasts should use the network journal which will help to publish their notes to podcasts. And they also should remember about subscription to their podcasts. RSS subscription is available at FeedBurner which allows easy subscribing to a podcast. Then they need a place in the Internet where to store their podcasts. They can use any website like Our Media because it freely stores online files [10].

If professors are eager to further develop communicative skills, they can organize forums using Chinswing, Vaestro or Blogspot. Forum communication will lead to the development of communicative skills, the increase of postgraduates' motivation and interest in further studying foreign languages.

Thus, university staff can easily create podcasts with tasks and publish them on websites, and students can subscribe to these podcasts and do the assignments. This type of work is individual, and it plays a great role in postgraduates' motivation while studying foreign languages.
As a result, using this podcast technology will contribute to the development of foreign communicative competences such as linguistic, sociocultural and interactive. This technology will allow overcoming some difficulties connected with different levels of postgraduates' knowledge, improve the quality of education and compensating the health disorders concerning communicative skills.

\section{B. The instructions how to teach listening using podcasts in the podosphere}

The podosphere forms a developing interest among postgraduates, positive cognitive motivation as podcasts provide students with actual, authentic and important information. When we study podcast material deeper, we become more interested in the studied topic.

When we use podcasts to form listening skills, it's necessary to do the following: 1) to study the number and topics of the offered podcasts (it means that we should take into account their relevance to the educational aims, to students' communicative and infocommunication competence); 2) to create a podcast (it will help a professor to realize what students feel when they are in a virtual world).

Professors should study podcasts before the lesson in order to avoid some unexpected questions, and students should be prepared to work with foreign podcasts; know how to create podcasts, to use them effectively, to look for new lingual information.

Listening and creating podcasts allow to form and to develop profile foreign competence among postgraduates in order to become experts in their professional field, because when they surf the Internet to find a suitable podcast they have to look through or to listen to podcasts in order to understand their educational relevance.

As we mentioned, professors should become podcasters to understand the virtual world and to teach listening efficiently using this technology. When professors create podcasts to develop listening skills, they have to listen to them and to do the prepared tasks themselves before they give these tasks to their students, because it's necessary to know in advance if the podcast material and tasks are right.

Another stage is to prepare students to work with such foreign podcasts and to teach them the ways of podcasts' creation using their knowledge of foreign languages. Students should be instructed how to choose the relevant style, what information to include, what language means to use and how to download podcasts. It's relevant to use public foreign podcasts from the company sites like BBC because their language is authentic and normative.

And the last stage is to download students' podcasts in the Internet, to work out tasks to their podcasts and to use them in a student group of the same speciality. Thus, students take part in creating and downloading podcasts, working out tasks to their own projects, but professors are their advisers who help and consult them.

There is one more aspect of teaching with the help of this technology: students should understand what kind of 
information they download in the Internet in order to avoid creating spam, offending other users and providing senseless or even harmful content [11].

\section{CONCLUSIONS}

Thus, this paper focuses on using the productive podcast model of forming listening skills while teaching postgraduates. Podcasting provides all participants of the educational process (professors, postgraduates) with free foreign educational environment which contributes to forming, developing and improving foreign cognitive and communicative activity (listening to authentic texts, socializing with native speakers). This technology also increases postgraduates' motivation and creativity.

Podcasts are effectively used to form and to develop foreign listening competence in any conditions because they are electronic means of transmission of sound information. The development of foreign listening competence is reached by creating and using different podcasts according to the educational aim of the Federal state educational standard.

The podosphere includes podcasters, profile podcasts and means of their creation, edition and transmission. Teaching in the podosphere guarantees asynchronic participation of the maximum number of students, access to the educational materials and podcasts, discontinuous communication between professors and students through podcasts. The podosphere is a standardized system which provides unification of audio and video files regardless of their content, and it's very important that this sphere is predominantly free (for creators and recipients), dynamic (regular publication of podcasts), simple (easy subscription), authentic (we can get recorded information from native speakers) and motivating (actual and profile information).

Thus, authenticity, interaction and profile orientation of this technology increases the effectiveness of forming foreign profile listening competence of postgraduates due to their availability and their correspondence to the curriculum. The most popular educational podcast services are iTunes, BBC.co.uk, Youtube.com, MirPod.

Forming and developing listening skills include listening to podcasts or their extracts in the classroom or in the out-class location. It's expedient to divide the lesson into three stages: preparatory tasks, tasks which are done while listening and tasks which are done after listening.
Teaching with the help of podcasts is more interactive, because it develops critical thinking and improves flexibility in teaching languages: podcasts develop listening skills and improve communicative skills when students take part in discussions of audio and video information despite their difficulties and disorders when they create their own podcasts with program means.

\section{REFERENCES}

[1] E.YU. Malushko, "Use of special virtual learning system for educating schoolchildren with disabilities", 2nd international multidisciplinary scientific conference on social sciences \& arts SGEM 2015: conference proceedings, Book 1. Psycology \& psychiatry, sociology \& healthcare, education, vol. 2, pp. 1155-1160, 2015.

[2] R. Blood, "The weblog handbook: Practical advice on creating and maintaining your blog", Cambridge, Persus publishing, 2002, p. 23.

[3] A. Puzatykh, "How to create a podcast? What is podcasting, podcast?", URL:http://alex-bestbusiness.com/kak-sozdat-blog/kak-sozdat-podkastchto-takoe-podkasting-podkast-podcast.html.

[4] V.G. Lizunkov, and M.G. Minin, "Developing a model of forming economic and managerial skills of bachelors in mechanical engineering", in Modern problems of science and education, vol. 6, p. $615,2014$.

[5] L. Lizunkov, M. Loschilova, and A. Zavyalova, "Professional Training of Bachelors in Mechanical Engineering Based on Networking Resources", in Procedia - Social and Behavioral Sciences, vol. 206, pp. 399-405, 2015.

[6] E. Malushko, O. Maletina, and V. Tsybaneva, "Teaching Discussion Skills As Part Of Further Teachers' Training", in Advances in Social Science Education and Humanities Research (ASSEHR), vol. 97, pp. 175-180, 2017.

[7] B.G. Meshcheryakov, and V.P. Zinchenko, "A significant psychological dictionary", SPb, Prime EVROZNAK, 2007.

[8] E. Malushko, O. Maletina, V. Lizunkov, and V. Tsybaneva, "Use of virtual learning system for educating students with disabilities and special needs", International Multidisciplinary Scientific Conferences on Social Sciences and Arts, pp. 481-487, 2016.

[9] C.H. Manzuoli, H.A.R. García, and Y.S. Cifuentes, "Training professors in ICT: Personal Learning Environments", in A grounded theory research study, Focus on: Performing Arts, Media and Training, vol. 12 (1), pp. 39-52, 2016.

[10] M. Hismanoglu, "Prospective EFL Teachers' Perceptions of ICT Integration: A Study of Distance Higher Education in Turkey", in Educational Technology and Society, vol. 15 (1), pp. 185-196, 2012.

[11] N.L. Shamne, and E.V. Shishkina, "German popular scientific medical online media: structural and functional aspects", in Vestnik Volgogradskogo Gosudarstvennogo Universiteta-seriya 2-yazykoznanie, vol. 16 (2), pp. 143-151, 2017 (In Russian). 